\title{
Status gizi berhubungan positif dengan derajat nyeri sendi penderita osteoartritis lutut
}

\author{
Nutritional status was positively associated with joint pain score in patients with knee osteoarthritis
}

Nyoman Kertia ${ }^{1}$

\begin{abstract}
Background: Knee osteoarthritis (OA) is a common disorder that is associated with significant morbidity, disability, and medical costs, particularly in its advanced stages. While the cause of knee OA remains unclear, it has been associated with various risk factors, such as age, sex, genetic predisposition, biomechanical, and obesity. Pain in osteoarthritis occurs due to combination of various factors. Pain significantly increases the medical and non medical cost in OA. Data showed that obesity will increase the mechanical stress and pain of knee OA. However, uncertainty remains regarding potential relationship between body mass index (BMI) and pain in osteoarthritis. Moreover, since obesity is one of modifiable and preventable risk factors for the onset and progression of the disease, it is important to know the correlation between $B M I$ and severity of pain in knee $O A$.

Objective: To investigate the relationship between body mass index and severity of joint pain in knee osteoarthritis.

Method: A cross sectional study was conducted and subjects were osteoarthritis patients in rheumatology clinic of Sardjito general hospital. Body mass index and visual analogue scale (VAS) score were measured. Correlation between $B M I$ and VAS score were analyzed by bivariate correlation test.

Results: There were 80 patients with osteoarthritis who participated in the study. Mean BMI was $26.36 \pm 4.23 \mathrm{~kg} / \mathrm{m}^{2}$ and VAS score was $52.40 \pm 24.53 \mathrm{~mm}$. The correlation test showed that there was a positive but non significant correlation between BMI and VAS scores ( $r=0,11 ; p=0,33)$.

Conclusion: There was a positive but non significant correlation between body mass index and the severity of joint pain in knee osteoarthritis.
\end{abstract}

KEY WORDS osteoarthritis, body mass index, joint pain, VAS score

\section{ABSTRAK}

Latar belakang: Osteoartritis (OA) lutut adalah salah satu penyakit yang sering terjadi dan berhubungan dengan angka kesakitan, ketidakmampuan, dan biaya pengobatan khususnya pada kondisi yang berat. Penyebab dari OA lutut belum jelas, penyakit ini berhubungan dengan berbagai faktor seperti umur, jenis kelamin, genetik, biomekanik, dan obesitas. Nyeri pada OA terjadi akibat kombinasi berbagai faktor. Nyeri pada OA meningkatkan biaya medis dan non medis secara signifikan. Beberapa data menunjukkan bahwa obesitas akan meningkatkan stres mekanik dan nyeri pada OA; namun masih belum jelas hubungan indeks masa tubuh (IMT) dan derajat nyeri pada OA. Obesitas merupakan salah satu faktor risiko yang dapat dimodifikasi dan dicegah untuk menghindari kejadian dan progresivitas penyakit, maka merupakan hal penting untuk mengetahui hubungan antara IMT dan derajat nyeri sendi pada OA.

Tujuan: Untuk mengetahui hubungan antara indeks masa tubuh dan derajat nyeri sendi pada osteoartritis lutut. Metode: Penelitian potong lintang dilakukan terhadap pasien osteoarthritis di poliklinik reumatologi RSUP Dr. Sardjito. Penilaian dilakukan terhadap IMT dan skor visual analogue scale (VAS). Hubungan antara IMT dan skor VAS dianalisis dengan korelasi bivariat.

Hasil: Sebanyak 80 pasien OA mengikuti penelitian ini. Rerata IMT adalah 26, $36 \pm 4,23 \mathrm{~kg} / \mathrm{m}^{2}$ dan skor VAS sebesar $52,40 \pm 24,53 \mathrm{~mm}$. Hasil analisis korelasi menunjukkan hubungan positif yang tidak bermakna antara IMT dan skor VAS $(r=0,11 ; p=0,33)$.

Kesimpulan: Ada hubungan positif namun tidak bermakna antara indeks masa tubuh dan derajat nyeri sendi pada penderita osteoartritis.

KATA KUNCI: osteoartritis, indeks masa tubuh, nyeri sendi, skor VAS

\section{PENDAHULUAN}

Osteoartritis (OA) merupakan penyakit sendi degeneratif yang berkaitan dengan kerusakan kartilago sendi. Tulang punggung, panggul, lutut, dan pergelangan kaki paling sering terkena OA. Prevalensi OA lutut radiologis cukup tinggi di Indonesia, yaitu mencapai $15,5 \%$ pada pria dan $12,4 \%$ pada wanita. Pasien OA umumnya mengeluh nyeri pada waktu melakukan aktivitas atau jika ada pembebanan pada sendi yang terkena. Pada derajat yang lebih berat, nyeri dapat dirasakan terus menerus sehingga

\footnotetext{
${ }^{1}$ Sub Bagian Reumatologi, Bagian IImu Penyakit Dalam Fakultas Kedokteran Universitas Gadjah Mada/ Rumah Sakit Umum Pusat Dr. Sardjito, Jl. Kesehatan No.1, Yogyakarta 55281, Telp (0274) 553119, e-mail: kertianyoman@yahoo.com
} 
sangat mengganggu mobilitas pasien. Prevalensi OA yang tinggi dan bersifat kronik progresif serta menimbulkan nyeri sendi, menyebabkan OA mempunyai dampak sosial ekonomi yang besar, baik di negara maju maupun di negara berkembang. Diperkirakan 1-2 juta orang usia lanjut di Indonesia menderita cacat karena OA (1).

Berbagai faktor risiko OA telah banyak diteliti dan salah satu yang berhubungan erat adalah berat badan yang berlebih. Obesitas mempunyai hubungan yang kuat dengan OA pada sendi lutut. Banyak studi populasi saat ini telah menemukan hubungan cross sectional antara obesitas dan OA pada sendi tibiofemoral dari lutut. Osteoartritis lutut secara radiografis rata-rata meningkat 4 kali lipat pada wanita obes, dengan odds ratio (OR) antara 2 sampai 9 (2).

Nyeri pada osteoartritis merupakan nyeri sendi degeneratif yang terjadi akibat kombinasi berbagai faktor, salah satunya adalah inflamasi. Nyeri merupakan gejala utama pada OA yang dimediasi oleh berbagai faktor. Nyeri merupakan hasil interaksi antara inflamasi dan berbagai faktor seperti keparahan penyakit secara radiologis, persarafan artikular, sensitisasi perifer dan sentral, serta faktor psikologis. Pengaruh status gizi terhadap keluhan nyeri pada pasien OA masih bersifat kontroversial. Hasil penelitian di New York (2007) melaporkan bahwa pasien OA dengan indeks massa tubuh (IMT) yang lebih tinggi, lebih banyak mengeluhkan nyeri (3). Hal ini berbeda dengan penelitian lainnya yang dilakukan di Florida, yang menunjukkan bahwa nyeri pada pasien OA tidak memiliki hubungan dengan status gizi (4).

Hubungan antara status gizi dan derajat nyeri menjadi menarik untuk diteliti lebih lanjut, oleh karena status gizi merupakan suatu faktor yang dapat dikendalikan terkait dengan upaya pengendalian gejala OA khususnya nyeri sendi yang akan memberikan dampak psikososial yang luas.

\section{BAHAN DAN METODE}

Penelitian ini menggunakan desain potong lintang (cross sectional study). Subjek adalah pasien osteoartritis lutut yang berobat di poliklinik Reumatologi RSUP Dr. Sardjito Yogyakarta. Kriteria inklusi adalah pasien osteoartritis lutut yang berumur lebih dari 50 tahun, subjek setuju mengikuti penelitian, dan menandatangani informed consent. Kriteria eksklusi adalah adanya penyakit artritis selain OA, penggunaan sendi prostesis, fraktur osteokondral, mendapat suntikan steroid intrartikular dalam 3 bulan terakhir atau hialuronat dalam 6 bulan terakhir, dan memiliki riwayat operasi lutut dalam 6 bulan terakhir.

Untuk mendapatkan besar sampel, dipergunakan rumus perhitungan untuk jenis penelitian analitik korelatif (5) dengan tingkat kepercayaan (1-a) sebesar 95\%, sehingga didapatkan nilai $\alpha=5 \%$ dengan $Z \alpha=1,65$; kekuatan penelitian (1- $\beta$ ) sebesar $80 \%$, sehingga didapatkan nilai $\beta=20 \%$ dengan $Z \beta=0,84$ dan $r=0,4$; dengan demikian besar sampel minimal yang diperlukan adalah 76 orang.

Dari 168 pasien OA yang berobat di poliklinik Reumatologi RSUP Dr. Sardjito, diperoleh 80 pasien yang memenuhi kriteria inklusi dan eksklusi. Subjek penelitian dilakukan washed - out selama 1 minggu kemudian dilakukan penilaian variabel penelitian. Penilaian derajat nyeri lutut dilakukan dengan penilaian skor kuesioner Visual Analogue Scale (VAS). Visual Analogue Scale merupakan garis lurus sepanjang $100 \mathrm{~mm}$. Titik $0 \mathrm{~mm}$ menunjukkan tidak ada rasa nyeri sama sekali, sedangkan titik $100 \mathrm{~mm}$ menunjukkan rasa nyeri paling hebat yang tidak tertahankan. Subjek penelitian mencentang pada titik nyeri yang dirasakan paling sesuai. Peneliti mengukur jarak (dalam $\mathrm{mm}$ ) antara titik $0 \mathrm{~mm}$ sampai ke titik tempat centangan subjek. Semakin jauh jarak antara titik $0 \mathrm{~mm}$ menuju titik centangan subjek berarti semakin berat nyeri yang dirasakan subjek. Nyeri derajat ringan ditunjukkan oleh skor VAS antara $0 \mathrm{~mm}$ sampai kurang dari $40 \mathrm{~mm}$, derajat sedang jika skor antara $40 \mathrm{~mm}$ sampai kurang dari $70 \mathrm{~mm}$, dan derajat berat jika skor $70 \mathrm{~mm}$ sampai $100 \mathrm{~mm}(6)$.

Selanjutnya semua penderita diukur status gizinya berdasarkan IMT dengan melakukan pengukuran berat badan dan tinggi badan. IMT atau body mass index (BMI) merupakan indikator status gizi yang cukup peka digunakan untuk menilai status gizi orang dewasa, khususnya yang berkaitan dengan kekurangan dan kelebihan berat badan. IMT adalah cara termudah untuk memperkirakan obesitas serta berkorelasi kuat dengan massa lemak tubuh, selain itu juga penting untuk mengidentifikasi pasien obes yang mempunyai risiko mendapat komplikasi medis. Perhitungan IMT mempunyai beberapa keunggulan utama yaitu menggambarkan lemak tubuh yang berlebihan, sederhana, dan bisa digunakan dalam penelitian populasi berskala besar $(7,8)$. Pengukurannya hanya membutuhkan 2 hal yakni berat badan dan tinggi badan, yang keduanya dapat dilakukan secara akurat oleh seseorang dengan sedikit latihan. Keterbatasannya adalah membutuhkan penilaian lain bila dipergunakan secara individual. Salah satu keterbatasan IMT adalah tidak bisa membedakan berat yang berasal dari lemak dan berat dari otot atau tulang. IMT juga tidak dapat mengidentifikasi distribusi lemak tubuh. Beberapa peneliti menyatakan bahwa standar cut off point untuk mendefinisikan obesitas berdasarkan IMT mungkin tidak menggambarkan risiko yang sama untuk konsekuensi gangguan kesehatan pada semua ras atau kelompok etnis (9).

Penilaian status gizi menggunakan indikator IMT $\left(\mathrm{kg} / \mathrm{m}^{2}\right)$ yang dihitung dengan rumus yaitu berat badan (BB dalam $\mathrm{kg}$ ) dibagi kuadran tinggi badan (TB dalam $\mathrm{m}$ ), kemudian dikategorikan berdasarkan batas ambang untuk orang Indonesia (10) yaitu: kekurangan BB tingkat berat 
jika IMT kurang dari 17; kekurangan BB tingkat ringan jika IMT sama dengan 17 sampai kurang dari 18,5; normal jika IMT sama dengan 18,5 sampai kurang dari 25 ; dan gemuk jika IMT lebih dari atau sama dengan 25. Hubungan antara nilai IMT dan skor VAS diuji dengan test korelasi bivariat.

\section{HASIL}

Sebagian besar subjek (66\%) adalah wanita. Usia rerata subjek penelitian adalah $64,31 \pm 8,79$ tahun, dengan kelompok usia terbanyak pada rentang usia 60-69 tahun. Tingkat pendidikan subjek penelitian yang terbanyak adalah SMA sebanyak 24 orang (30\%). Terkait dengan keluhan OA yang dialami, sebagian besar $(43,75 \%)$ subjek mengeluhkan adanya nyeri derajat sedang dengan rerata skor VAS sebesar 52,40 $\pm 24,53 \mathrm{~mm}$. Berdasarkan perhitungan status gizinya, rata-rata subjek memiliki berat badan berlebih (rerata IMT adalah 26,36 $\pm 4,23 \mathrm{~kg} / \mathrm{m}^{2}$ ). Dari 80 subjek penelitian diperoleh sebagian besar $(63,75 \%)$ tergolong status gizi lebih (IMT $\geq 25 \mathrm{~kg} / \mathrm{m}^{2}$ ) (Tabel 1).

Setelah melalui uji distribusi, didapatkan sebaran data IMT dan skor VAS mengikuti kurva normal. Selanjutnya untuk mengetahui hubungan antara status gizi yang dinilai dengan IMT dan derajat nyeri sendi yang dinilai dengan skor VAS maka dilakukan uji korelasi Pearson. Berdasarkan uji korelasi didapatkan adanya korelasi positif yang tidak bermakna antara status gizi dengan derajat nyeri sendi $(r=0,11 ; p=0,33)$. Koefisien korelasi Pearson (r) mengukur kekuatan hubungan linier antara dua variabel kuantitatif. Pada penelitian ini didapatkan korelasi positif
Tabel 1. Karakteristik data dasar subjek penelitian

\begin{tabular}{|c|c|c|}
\hline Variabel & $\begin{array}{c}\text { Jumlah (\%) } \\
n=80\end{array}$ & Rerata $\pm S D$ \\
\hline Jenis kelamin & & - \\
\hline Pria & $27(34)$ & \\
\hline Wanita & $53(66)$ & \\
\hline Usia (tahun) & & $64,31 \pm 8,79$ \\
\hline \multicolumn{3}{|l|}{ 50-59 } \\
\hline \multicolumn{3}{|l|}{$60-69$} \\
\hline \multicolumn{3}{|l|}{70 ke atas } \\
\hline Pendidikan (\%) & & - \\
\hline Tidak tamat SD & $5(6,2)$ & \\
\hline SD & $11(13,8)$ & \\
\hline SMP & $22(27,5)$ & \\
\hline SMA & $24(30)$ & \\
\hline Sarjana & $18(22,5)$ & \\
\hline Lama OA (bulan) & & $43,07 \pm 31,57$ \\
\hline Lokasi OA (\%) & & - \\
\hline Lutut kanan & $43(53,8)$ & \\
\hline Lutut kiri & $28(35)$ & \\
\hline Bilateral & $9(11,2)$ & \\
\hline IMT $\left(\mathrm{kg} / \mathrm{m}^{2}\right)$ & & $26,36 \pm 4,23$ \\
\hline Status gizi kurang $(<18,5)$ & $2(2,5)$ & \\
\hline Status gizi baik $(18,5-25)$ & $27(33,75)$ & \\
\hline Status gizi lebih $(\geq 25)$ & $51(63,75)$ & \\
\hline VAS $(\mathrm{mm})$ & & $52,40 \pm 24,53$ \\
\hline Derajat ringan (0-39) & $24(30)$ & \\
\hline Derajat sedang (40-69) & $35(43,75)$ & \\
\hline Derajat berat $(70-100)$ & $21(26,25)$ & \\
\hline
\end{tabular}

Keterangan: SD = standar deviasi

$\mathrm{OA}=$ osteoartritis

IMT = indeks massa tubuh

VAS = visual analogue scale

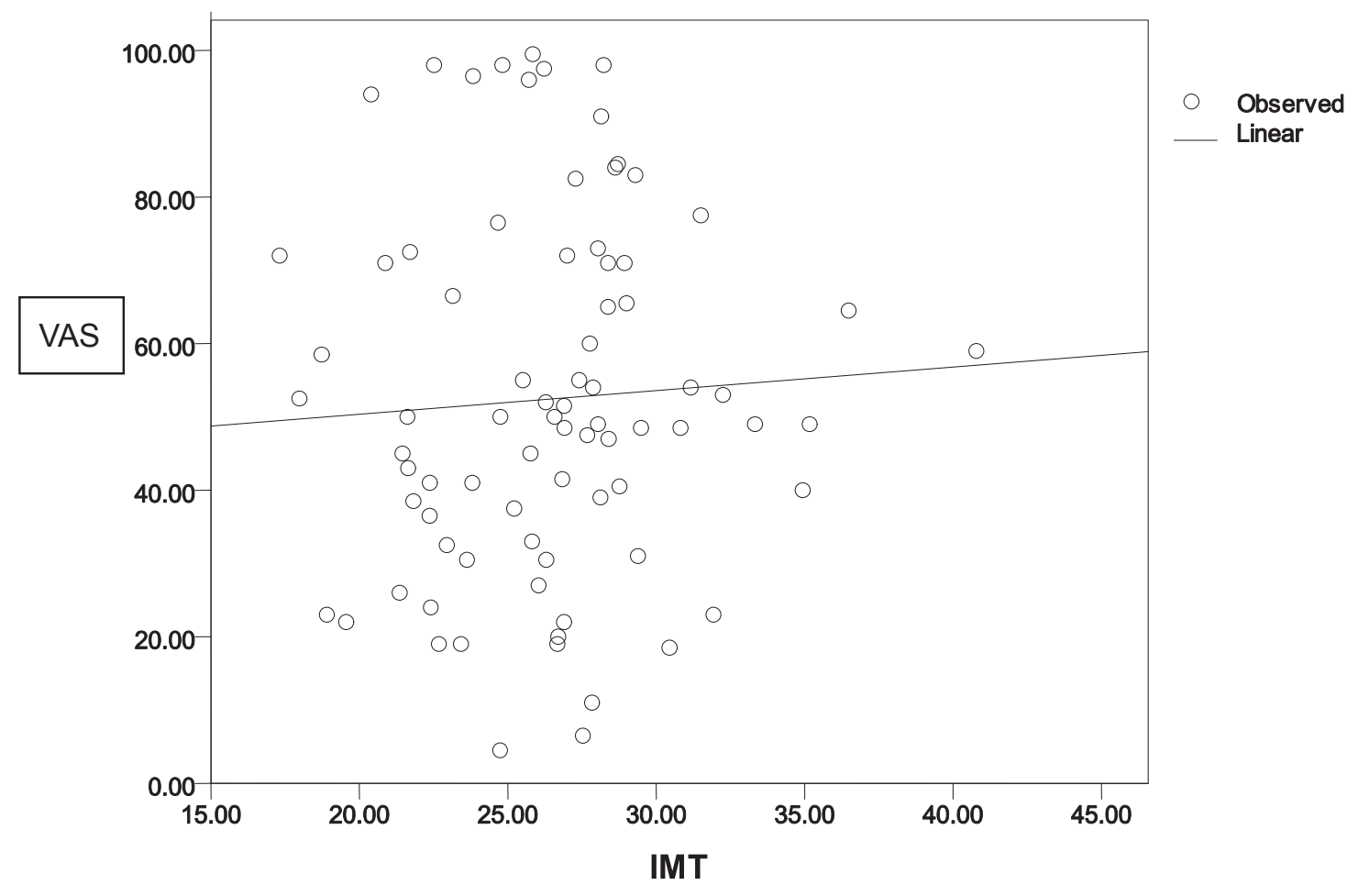

Gambar 1. Kurva regresi antara indeks masa tubuh (IMT) dengan skor visual analogue scale (VAS) 
Tabel 2. Rerata skor VAS berdasarkan IMT

\begin{tabular}{lc}
\hline \multicolumn{1}{c}{ Indeks masa tubuh $\left(\mathbf{k g} / \mathbf{m}^{2}\right)$} & Skor VAS $\mathbf{( m m})$ \\
\hline$<18,5$ (status gizi kurang) & $46,75 \pm 8,13$ \\
$18,5-<25$ (status gizi normal) & $48,89 \pm 26,83$ \\
$\geq 25$ (status gizi lebih) & $54,25 \pm 23,28$ \\
\hline
\end{tabular}

Keterangan: VAS = visual analogue scale

Tabel 3. Distribusi skor VAS berdasarkan IMT

\begin{tabular}{ccccc}
\hline \multirow{2}{*}{ IMT $\left(\mathbf{k g} / \mathbf{m}^{2}\right)$} & \multicolumn{4}{c}{ Skor VAS $(\mathbf{m m})$} \\
\cline { 2 - 5 } & $\mathbf{0 - < \mathbf { 4 0 }}$ & $\mathbf{4 0 - < \mathbf { 7 0 }}$ & $\mathbf{7 0 - 1 0 0}$ & Total \\
\hline$<18,5$ & 0 & 1 & 1 & 2 \\
$18,5-<25$ & 12 & 8 & 7 & 27 \\
$\geq 25$ & 12 & 26 & 13 & 51 \\
Total & 24 & 35 & 21 & 80 \\
\hline
\end{tabular}

Keterangan: VAS = visual analogue scale

IMT = indeks massa tubuh

antara status gizi (nilai IMT) dengan derajat nyeri sendi (skor VAS) dengan koefisien korelasi Pearson ( $r$ ) sebesar 0,11 . Hal ini menunjukkan bahwa nilai IMT yang tinggi berkorelasi positif dengan skor VAS yang tinggi. Hasil analisis menunjukkan nilai signifikansi $(p)$ sebesar 0,33 yang berarti bahwa terdapat korelasi positif namun tidak bermakna antara status gizi dengan derajat nyeri sendi.

Gambar 1 menunjukkan kurva regresi antara IMT dengan derajat nyeri lutut yang terserang OA. Tampak bahwa semakin tinggi IMT maka nyeri lutut yang dirasakan oleh penderita OA semakin hebat.

Rerata skor VAS tertinggi atau rasa nyeri paling hebat didapatkan pada kelompok yang mempunyai status gizi berlebih dan rerata skor VAS terendah atau rasa nyeri paling ringan didapatkan pada kelompok yang mempunyai status gizi kurang (Tabel 2).

Nyeri derajat sedang dan derajat berat dengan IMT berlebih adalah dominan dialami oleh subjek penelitian. Hanya 2 subjek yang mempunyai IMT kurang dari normal (Tabel 3). Adanya sel yang mempunyai nilai 0 (nul) menyebabkan analisis statistik non parametik untuk mengetahui perbedaan intensitas nyeri berdasarkan IMT tidak dilakukan, namun hasil analisis korelasi yang dilakukan telah menggambarkan bahwa semakin tinggi IMT maka semakin hebat nyeri lutut yang dirasakan subjek penelitian.

\section{BAHASAN}

Osteoartritis lutut merupakan penyakit degeneratif yang sampai sekarang masih belum diketahui dengan pasti penyebabnya. Osteoartritis juga merupakan penyakit rematik kronik yang paling sering ditemui. Banyak hal yang dapat menjadi faktor risiko penyakit ini, salah satu di antaranya adalah obesitas. Angka kejadian penyakit ini pun bertambah seiring dengan bertambahnya usia. OA umumnya menyerang pada usia di atas 50 tahun (11).
Osteoartritis sendi lutut ditandai oleh adanya rasa nyeri pada pergerakan yang hilang bila istirahat, kaku sendi terutama setelah istirahat atau bangun tidur, krepitasi, dan dapat disertai sinovitis dengan atau tanpa efusi sendi. Umumnya penderita OA lutut datang berobat karena rasa nyeri lutut yang mengganggu aktivitas sehari-hari. Gangguan tersebut bervariasi, mulai keluhan yang paling ringan yang tidak mengganggu aktivitas sehari-hari, sampai yang paling berat sehingga pasien tidak bisa berjalan (12).

Dari 80 subjek penelitian diperoleh sebanyak 53 wanita (66\%) dan 27 pria (34\%). Lebih banyaknya subjek wanita sesuai dengan data epidemiologi penyakit osteoartritis yang menunjukkan bahwa prevalensi osteoartritis lebih tinggi pada wanita dibandingkan pria (13). Rerata usia subjek penelitian adalah $64,31 \pm 8,79$ tahun, hal ini sesuai dengan prevalensi osteoartritis yang bersifat degeneratif dan lebih banyak menyerang usia lanjut. Prevalensi OA meningkat dengan meningkatnya umur (13).

Berdasarkan status gizi subjek penelitian juga diperoleh data bahwa risiko OA lebih banyak ditemukan pada kelompok dengan status gizi lebih yaitu sebanyak 51 orang $(63,75 \%)$. Hal ini sesuai dengan studi di Inggris yang menunjukkan bahwa untuk setiap peningkatan IMT sebesar 2 unit, OR untuk menderita OA lutut secara radiografik meningkat sebesar 1,36 poin. Penelitian tersebut juga menyimpulkan bahwa semakin tinggi berat badan maka risiko menderita OA lutut semakin meningkat. Kehilangan $5 \mathrm{~kg}$ berat badan akan mengurangi risiko OA lutut secara simtomatik pada wanita sebesar $50 \%$. Demikian juga peningkatan risiko mengalami OA lutut yang progresif tampak pada orang-orang yang kelebihan berat badan. Obesitas diketahui merupakan faktor risiko terkuat yang dapat dimodifikasi. Selama berjalan, setengah berat badan bertumpu pada sendi lutut. Peningkatan berat badan akan melipatgandakan beban sendi lutut saat berjalan (14).

Terkait dengan patogenesis OA, faktor risiko mekanik, biokimia, dan genetik dinilai berperan penting. Adanya beban berlebih dinilai menjadi alasan peningkatan risiko OA pada pasien dengan berat badan lebih. Penelitian pada rawan sendi menunjukkan adanya mekanoreseptor pada permukaan kondrosit yang sensitif terhadap tekanan dan mampu menyebabkan cascade sinyal intraselular. Terdapat 3 jenis mekanoreseptor pada kondrosit yaitu stretch activated channels, alfa-5b1 integrin, dan CD44. Tekanan dan regangan menstimulasi integrin dan stretch activated channels. Setelah adanya aktivasi mekanoresptor kemudian sitokin, growth factor, dan metalloproteinase diekspresikan, kemudian diproduksi pula berbagai mediator seperti prostaglandin atau nitrit oxide (NO). Penelitian eksperimental menunjukkan pada kondisi tertentu, kelebihan beban memacu proses degradasi kartilago sekaligus menginhibisi sintesis matriks (15). 
Meskipun proses mekanik berperan pada kerusakan rawan sendi pada pasien obes, namun adanya penumpukan jaringan adiposa pada kondisi tersebut dianggap memberi peranan tersendiri.

Penelitian di Perancis membuktikan adanya hubungan yang positif antara berat badan berlebih dan rasa nyeri pada OA tidak hanya OA lutut namun juga OA tangan. Lebih jauh lagi, pengurangan lemak tubuh tampak berpengaruh terhadap penurunan gejala pada OA. Jaringan adiposa saat ini mulai dianggap sebagai organ endokrin tersendiri yang mampu melepaskan berbagai mediator inflamasi seperti interleukin-1 (IL-1), tumor nekrosis faktor alfa (TNF- $\alpha$ ), adiponektin, resistin, dan sebagainya. Penelitian menunjukkan kadar ekspresi leptin berhubungan dengan derajat kerusakan rawan sendi. Adanya peningkatan ekspresi leptin pada kartilago yang rusak berhubungan dengan kerusakan rawan sendi, khususnya jika dihubungkan dengan faktor-faktor lokal (16).

Hasil analisis korelasi yang positif namun tidak bermakna pada penelitian ini dimungkinkan karena nyeri dan patofisologi OA tidak hanya disebabkan oleh satu faktor saja. Kombinasi dari berbagai faktor yang berperan pada kerusakan sendi berperan juga dalam menimbulkan rasa nyeri pada subjek. Adanya kombinasi dari faktor nosiseptif, neurogenik, dan psikogenik berperan pada derajat nyeri yang dirasakan pasien, khususnya pada kondisi yang kronik. Nyeri yang bersifat kronik progresif ini tampak semakin berat seiring lamanya menderita penyakit OA (17).

Penelitian di India melibatkan 180 subjek dengan diagnosis osteoartritis lutut dan diklasifikasikan menurut skor Kellgren-Lawrence (KL). IMT, lingkar lengan atas (LLA), rasio pinggang pinggul, dan ketebalan kulit trisep dicatat dengan prosedur standar. Skor hasil Western Ontario Macmaster Osteoartritis Questionnaire (WOMAC) dievaluasi. Hasil penelitiannya diperoleh bahwa pada kedua jenis kelamin, IMT secara signifikan lebih tinggi untuk kelas $4 \mathrm{KL}$ daripada untuk kelas 2. Ketebalan kulit trisep berkorelasi positif dengan lebar ruang sendi dari kompartemen medial tibia.

Pada laki-laki, ketebalan kulit trisep meningkat secara signifikan sesuai dengan peningkatan gradasi $\mathrm{KL}$ dari 2 ke 4. IMT yang secara signifikan lebih tinggi ditemukan pada lutut varus berkorelasi positif dengan skor WOMAC. Pada wanita, rasio pinggang pinggul secara signifikan lebih tinggi untuk kelas $4 \mathrm{KL}$ dari pada untuk kelas 2 . Korelasi yang signifikan ditemukan antara IMT dan skor WOMAC. Rasio pinggang pinggul secara bermakna dikaitkan dengan lutut varus dan berkorelasi positif dengan skor WOMAC dan lebar ruang sendi dari kompartemen medial tibia. LLA menunjukkan tidak ada korelasi dengan kelas $\mathrm{KL}$ pada osteoartritis lutut. Penelitian ini memvalidasi bahwa IMT dan pengukuran antropometrik lainnya memiliki hubungan yang signifikan dengan kelas $\mathrm{KL}$ pada osteoartritis lutut. Ketebalan lipatan kulit trisep (lemak perifer) pada laki-laki dan rasio pinggang-pinggul (lemak sentral) pada wanita tidak hanya terkait dengan tingginya IMT, tetapi juga berhubungan dengan kelas KL dari OA lutut (18).

Hasil penelitian di Inggris menilai pola longitudinal pada IMT selama 14 tahun dan hubungannya dengan nyeri lutut. Studinya melibatkan 594 perempuan dengan data IMT dari kunjungan klinik di tahun ke-1, 5, 10, dan 15. Nyeri lutut pada tahun ke-15 dinilai dengan kuesioner. Hubungan antara IMT lebih dari 14 tahun dan nyeri lutut di tahun ke-15 dinilai menggunakan regresi logistik. Diperoleh hasil bahwa IMT secara signifikan meningkat dari tahun ke-1 sampai tahun ke-15 $(p<0,0005)$ dengan masing-masing median (kisaran interkuartil) dari 24,5 $\mathrm{kg} / \mathrm{m}^{2}\left(22,5-27,2 \mathrm{~kg} / \mathrm{m}^{2}\right)$ dan $26,5 \mathrm{~kg} / \mathrm{m}^{2}(23,9-30,1 \mathrm{~kg} /$ $\mathrm{m}^{2}$ ). Pada tahun ke-15, 45,1\% subjek mengalami nyeri lutut. IMT yang lebih besar pada tahun ke-1 (OR=1,34; $95 \%$ confidence interval $[95 \% \mathrm{Cl}]: 1,05-1,69)$, pada tahun ke-15 (OR=1,34; 95\%Cl:1,10-1,61), dan perubahan pada IMT selama 15 tahun $(\mathrm{OR}=1,40 ; 95 \% \mathrm{Cl}: 1,00-1,93)$ adalah prediktor signifikan dari nyeri lutut di tahun ke-15 $(p<0,05)$. Perubahan IMT dikaitkan dengan nyeri lutut bilateral $(\mathrm{OR}=1,61 ; 95 \% \mathrm{Cl}: 1,05-1,76 ; \mathrm{p}=0,024)$ namun tidak unilateral $(\mathrm{OR}=1,22 ; 95 \% \mathrm{Cl}: 0,73-1,76 ; \mathrm{p}=0,298)$.

Hubungan antara perubahan IMT dan nyeri lutut tidak terkait dengan radiografi osteoartritis lutut. Kekuatan hubungan antara IMT dan nyeri lutut di tahun ke-15 konsisten selama periode tindak lanjut pengukuran. Berdasarkan hasil penelitian tersebut dapat disimpulkan bahwa selama 14 tahun, IMT yang lebih tinggi memprediksi nyeri lutut di tahun ke-15 pada wanita. Ketika disesuaikan, hubungan itu signifikan pada nyeri lutut bilateral, bukan unilateral. Hal ini menunjukkan adanya kemungkinan alternatif mekanisme patologis. Efek longitudinal IMT pada nyeri lutut di tahun ke-15 sama pentingnya pada setiap titik waktu (19).

Hubungan yang signifikan antara penurunan berat badan dan pengurangan tekanan pada sendi lutut menunjukkan bahwa untuk setiap penurunan berat badan 1 pound, ada pengurangan beban pada sendi lutut sebesar 4 pound setiap langkahnya. Meskipun belum ada studi menunjukkan bahwa penurunan berat badan pada manusia memperlambat perkembangan OA lutut, namun sudah banyak bukti yang menunjukkan bahwa penurunan berat badan berhubungan dengan kejadian OA lutut. Hasil penelitian di Amerika Serikat mengungkapkan bahwa kehilangan berat badan 11,2 pound selama periode 10 tahun, dapat menurunkan kemungkinan kejadian OA lutut sebesar $50 \%$ (20).

IMT yang tinggi telah terbukti menjadi faktor risiko terjadinya osteoartritis pada lutut pinggul dan tangan. American College of Rheumatology merekomendasikan penurunan berat badan bagi orang-orang yang menderita 
OA lutut dengan kelebihan berat badan. Obesitas telah terbukti sangat berhubungan dengan OA lutut untuk semua etnis dan jenis kelamin. Analisis yang dilakukan oleh National Health and Nutrition Examination Survey (NHANES) menunjukkan data bahwa orang dewasa di Amerika Serikat dengan IMT lebih dari $30 \mathrm{~kg} / \mathrm{m}^{2}$ memiliki prevalensi 4 kali lipat lebih tinggi terjadi OA lutut dibandingkan dengan IMT kurang dari $30 \mathrm{~kg} / \mathrm{m}^{2}$.

Demikian pula hasil studi longitudinal menunjukkan bahwa peningkatan BMI pada orang dewasa berusia muda dan menengah meningkatkan risiko terjadinya OA. Dalam studi yang lain dikatakan, BMl yang tinggi pada pria muda berusia 20-29 tahun berhubungan dengan peningkatan risiko OA lutut dikemudian hari. Faktor metabolik juga ada hubungannya dengan kelebihan berat badan dan rasa nyeri. Orang-orang dengan kelebihan berat badan memiliki peningkatan risiko berbagai gangguan metabolisme, sehingga terjadi peningkatan kerentanan terhadap gangguan neuropatik (21).

Terdapat hubungan kuat antara obesitas dan kejadian OA. Obesitas ditimbulkan oleh kelebihan nutrisi dan resistensi insulin, terkait erat dengan kelebihan produksi sitokin pro inflamasi. Hal ini terlihat pada inflamasi kronik. Gizi berlebih menghasilkan reaktif oksigen spesies dalam jumlah banyak, sehingga terjadi stres oksidasi yang merusak sel dan memicu respon inflamasi. Seiring dengan resistensi insulin yang berlangsung, proses inflamasi juga meningkat. Dapat dikatakan bahwa asupan nutrisi yang berlebih bisa menimbulkan obesitas dan resistensi insulin yang akan memicu stres oksidatif dan respon inflamasi.

Target penyebab inflamasi dalam tubuh merupakan faktor penting dalam manajemen OA. Intervensi terhadap gaya hidup yang dilakukan secara agresif membantu mengurangi respon inflamasi. Aktivitas yang tidak banyak beban seperti berenang telah terbukti mengurangi gejala, meningkatkan mobilitas, dan mengurangi kerusakan dari OA. Menurunkan berat badan, mengurangi faktor risiko untuk terjadinya rasa nyeri pada lutut serta mengurangi sitokin pro-inflamasi dan adipokines yang diyakini memainkan peran dalam degradasi tulang rawan akan mengurangi nyeri terkait $\mathrm{OA} \mathrm{sehingga} \mathrm{dapat} \mathrm{meningkatkan}$ aktivitas fisik (22).

\section{KESIMPULAN DAN SARAN}

Terdapat korelasi positif namun tidak bermakna antara status gizi berdasarkan indeks massa tubuh dengan derajat nyeri sendi pada osteoartritis lutut.

Adanya kecenderungan bahwa semakin tinggi indeks massa tubuh maka derajat nyeri lutut penderita OA akan semakin berat, sehingga disarankan agar pasien-pasien osteoartritis tidak memiliki berat badan yang berlebih dengan cara mengatur diit seimbang ditambah exercise yang terpilih seperti berenang dan naik sepeda.

\section{UCAPAN TERIMA KASIH}

Peneliti mengucapkan terimakasih kepada dr. Sri Endarin, MPH yang pada saat penelitian berlangsung menjabat sebagai Direktur Utama RSUP. Dr. Sardjito, atas bantuan dan perhatian beliau dalam penelitian ini. Terimakasih pula kepada para residen dan perawat di poliklinik Reumatologi RSUP Dr. Sardjito yang telah membantu dalam penelitian ini.

\section{RUJUKAN}

1. Soeroso J, Isbagio $H$, Kalim $H$, Broto R, Pramudiyo R. Osteoartritis. Dalam: Sudoyo A, Setiyohadi B, Alwi I. Buku ajar ilmu penyakit dalam. Jakarta: Pusat Penerbitan Ilmu Penyakit Dalam Fakultas Kedokteran Universitas Inonesia; 2009.

2. Nisha JM, Hart D, Spector TD, MacGregor AJ. The association of body mass index and osteoarthritis of the knee joint an examination of genetic and environmental influences. Arthritis Rheum 2003;48(4):1024-9.

3. Marks R. Obesity profiles with knee osteoarthritis: correlation with pain, disability and disease progression. Obesity 2007;15(7):1867-74.

4. Rogers MW, Wilder FV. The association of BMI and knee pain among persons with radiographic knee osteoarthritis: a cross-sectional study. BMC Musculoskelet Disord 2008;9:163-70.

5. Dahlan. Langkah-langkah membuat proposal penelitian. Jakarta: Sagung Seto; 2009.

6. Ardyasih, Rahardjo P, Kertia, N. Nilai kesepakatan dokter-pasien dan pasien-pasien dari kuesioner visual analogue scale untuk pasien osteoartritis lutut di rumah sakit Dr. Sardjito Yogyakarta. Dalam: Setyohadi B, Kasjmir YI. Naskah Lengkap Temu IImiah dan Kursus Nyeri. Jakarta: Ikatan Reumatologi Indonesia; 2004.

7. Arisman. Gizi dalam daur kehidupan. Palembang: Bagian Gizi Fakultas Kedokteran Universitas Sriwijaya; 2002.

8. RippeJ, Mclnnis K, MelansonK. Physician involvement in the management of obesity as a primary medical condition. Obesity research 2001;9:302-11.

9. National Institutes of Health. Strategic plan for $\mathrm{NIH}$ obesity research. U.S. Department of Health and Human Services: NIH Publication No. 11-5493; 2011.

10. Direktorat Gizi Masyarakat, Ditjen Binkesmas, Depkes RI. Pedoman umum gizi seimbang. Jakarta: Depkes RI; 2002.

11. Isbagio $\mathrm{H}$. Tiga hal yang paling menonjol dari 100 lebih jenis rematik. Jakarta: Smart Living edisi 16; 2009.

12. Isbagio H. Pendekatan diagnostik penyakit reumatik. Cermin Dunia Kedokteran 1995:78.

13. Breedveld FC. Osteoarthritis the impact of a serious disease. Rheumatol 2004;43(Suppl 1):14-8. 
14. Felson DT. Osteoarthritis new insights. Part 1: the disease and its risk factors. Ann Intern Med 2000;133:637-9.

15. Ranitya $R$, Isbagio $H$. Epidemiologi dan faktor risiko osteoarthritis. Dalam: Pramudiyo R, Wachjudi RG, Hamijoyo L. Makalah Lengkap Kursus Osteoartritis; 28-30 January 2005; Bandung.

16. Pottie P, Presle N, Terlain B, Netter P, Mainard D, Berenbaum F. Obesity and osteoarthritis: more complex than predicted. Ann Rheum Dis 2006;65:1403-05.

17. Kertia N, Khomimah H. Peran inflamasi terhadap nyeri dan progresivitas osteoarthritis. Dalam: Setiyohadi B, Kasjmir YI. Naskah Lengkap Temu IImiah Reumatologi Indonesia. Jakarta: Pusat Informasi dan Penerbitan Departemen IImu Penyakit Dalam FK-UI; 2005.

18. Sanghi D, Srivastava RN, Singh A, Kumari R, Misra R, Misra A. The association of anthropometric measures and osteoarthritis knee in non-obese subjects: a cross sectional study. Clinics 2011;66(2):275-9.

19. Goulston LM, Kiran A, Javait MK, Soni A, White KM, Hart DJ, Spector TD, Arden NK. Does obesity predict knee pain over fourteen years in women, independently of radiographic changes? Arthritis Care Res 2011;63(10):1398-406.

20. Meisser SP, Gutekunst DJ, Davis C, Devita P. Weight loss reduces knee-joint loads in overweight and obese older adults with knee osteoarthritis. Arthritis Rheum 2005;52(7):2026-32.

21. Janke EA, Collins A, Kozak AT. Overview of the relationship between pain and obesity: what do we know? where do we go next?. J Rehabil Res Dev 2007;44(2):245-62.

22. Wolhurter T, Till A. Nutritional management of osteoarthritis. Medical Chronicle 2010;73. 